\title{
MERCURY IN THE SEDIMENT OF THE UPPER PARNAÍBA RIVER
}

\author{
Marcelo B. Remor ${ }^{1}$, Silvio C. Sampaio ${ }^{2 *}$, Danielle M. Rosa ${ }^{1}$, Kathleen J. Model ${ }^{1}$, \\ Cristiane L. Paloschi ${ }^{1}$, Fagner G. da Conceição ${ }^{3}$
}

${ }^{2 *}$ Corresponding author. Universidade Estadual do Oeste do Paraná/ Cascavel - PR, Brasil. E-mail: silvio.sampaio@unioeste.br

\section{KEYWORDS}

trace elements, agricultural frontier, heavy metal.

\begin{abstract}
The contamination of aquatic environments with chemical trace elements can be evaluated by their accumulation in sediments of the water body. Studies on mercury require the use of exclusive extraction techniques that have relatively high costs when compared to the analysis of other trace elements. This study was conducted aiming at determining the mercury concentration in sediments of the Upper Parnaíba River basin, located in a region of agricultural expansion between the states of Piauí and Maranhão. The sediment was collected at 12 sites in the basin. After drying, the quantification of total mercury was performed by the Zeeman atomic absorption spectrometry coupled to a pyrolysis reactor. Mercury concentrations in sediments of the Parnaíba River ranged from 4.2 to $58.5 \mathrm{ng} \mathrm{g}^{-1}$ and presented a low probability of adverse effects on biota. Mercury had no correlation with the variables clay, silt, sand, total organic carbon, iron, and aluminum, demonstrating its possible anthropogenic origin. Although mercury concentrations have a low probability to disturb the balance of the local ecosystem, there is a need for monitoring the region in order to quantify the risks to biota and human health.
\end{abstract}

\section{INTRODUCTION}

The Parnaíba River basin is the second most important in the Northeast of Brazil, located in a region of expansion of the agricultural frontier in the CentralNortheastern direction called Matopiba, which covers the states of Maranhão, Tocantins, Piauí, and Bahia (Freitas \& Mendonça, 2016; Santos, 2015, Garcia \& Buainain, 2016). However, in spite of providing regional economic development, agricultural activities practiced in an intense and disorderly manner can cause problems of contamination of the soil and water resources by surface runoff and leaching, causing, for instance, changes in the concentration of metals, such as mercury (Andrade et al., 2017; Cabral et al., 2016; Hu et al., 2015). The United Nations Environmental Programs establishes the use of pesticides, biocides, and topical antiseptics as one of the anthropogenic sources of mercury (UNEP, 2017).

Mercury concentrations in the environment become worrying due to their toxicity, persistence, bioaccumulation capacity, and biomagnification, causing adverse effects to the environment and human health (Kim et al., 2016; Selin, 2014). These effects on organisms exposed to mercury depend primarily on its chemical form and concentration in the environment, the route of exposure to the agent, and the difference in vulnerability between exposed organisms (Kim et al., 2016). When in humans, high mercury concentrations cause disturbances in the central and immune systems, kidneys, heart, reproductive, and genetic problems, and reductions in cognitive functions (Oliveira et al., 2013; Gibb \& O'Leary, 2014).

Mercury contamination can occur through air, water, and food (Syversen \& Kaur, 2012). Mercury in the aquatic environment is adsorbed by suspended particles, which are sedimented in low-energy environments (Zhang et al., 2014; Kim et al., 2016). The mercury adsorbed by the sediment can be converted into methylmercury $\left(\mathrm{CH}_{3} \mathrm{Hg}\right)$ by biological processes, which is a more toxic compound than the original chemical element.

The total mercury concentrations in surface sediments vary from 0.02 to $0.4 \mu \mathrm{g} \mathrm{g}^{-1}$ in uncontaminated rivers and can reach $100 \mu \mathrm{g} \mathrm{g}^{-1}$ in urban, industrial, or mining drainage rivers (Ullrich et al., 2001). Thus, the sediment is considered an important tool in determining the contaminants, acting as a reservoir of pollutant particles and source of secondary pollution of the aquatic environment (Castillo et al., 2013; Molamohyeddin et al., 2017; Resongles et al., 2014).

In recent years, several studies have been carried out to determine the concentration of heavy metals in river

\footnotetext{
${ }^{1}$ Universidade Estadual do Oeste do Paraná/ Cascavel - PR, Brasil.

${ }^{3}$ Universidade Tecnológica Federal de Paraná/ Dois Vizinhos - PR, Brasil.

Received in: 4-6-2018
}

Accepted in: 8-8-2018 
sediments in Brazil and in the World, such as Andrade et al. (2017), Bai et al. (2016), Begy et al. (2016), Franz et al. (2013), Franz et al. (2014), Poitrasson et al. (2014), Resongles et al. (2014), Silva et al. (2013), and Voigt et al. (2016). However, due to the need for unique extraction techniques and the cost of analyses, studies involving mercury are in less number (Franklin et al., 2012). In this sense, the studies of Araujo et al. (2015), Cabral et al. (2016), Hu et al. (2015), Remor et al. (2015), Sahoo et al. (2015), and Remor et al. (2018) stand out. Thus, the aim of this study was to determine the total mercury concentrations in sediments of the Upper Parnaíba River basin because it is a new Brazilian agricultural frontier and does not yet have records related to mercury concentration in sediments in rivers of the region.

\section{MATERIAL AND METHODS}

\section{Study area}

The Parnaíba River basin is located on the border of the states of Piauí, Maranhão, and Ceará, (Figure 1). The Parnaíba River is approximately $1,400 \mathrm{~km}$ long. Its main tributaries are the rivers Balsas, Gurguéia, Piauí, Canindé, Poti, and Longá, being considered as the largest river genuinely from northeastern Brazil. It has a drainage area of $331,441.5 \mathrm{~km}^{2}$ divided into three large sub-basins, the Low, Medium, and High Parnaíba River, as shown in Figure 1. The Parnaíba River presents a high hydroelectric potential, besides being widely used for urban supply and irrigation.

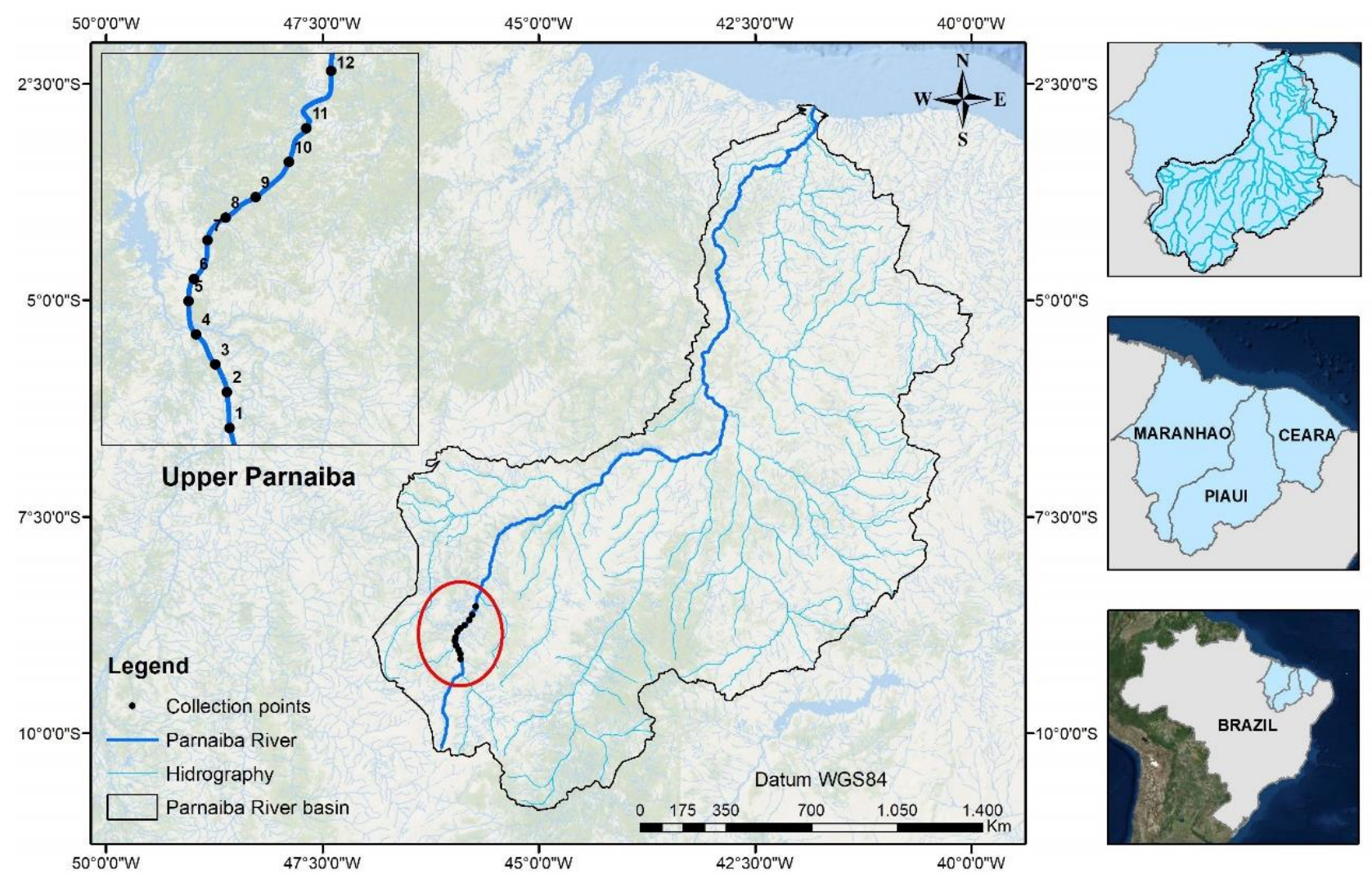

FIGURE 1. Geographical location of the study area.

The Upper Parnaíba River sub-basin (Figure 1) has a drainage area of $151,630.3 \mathrm{~km}^{2}$. Its main tributaries are the rivers Balsas, Uruçuí Preto River, Uruçuí Vermelho, Gurguéia, and Itaueiras. It presents an average annual precipitation of 4,373.6 $\mathrm{mm}$. The Upper Parnaíba River sub-basin is located in the Cerrado macro-region and has a predominantly savanna vegetation. The soils are classified as Oxisols (Latossolo Amarelo, Brazilian Soil Classification System) with a clayey texture, deep profile, good to moderate drainage, and usually considered from acid to very acid (Motta \& Gonçalves, 2016). This subbasin is weakened by activities carried out in the drainage area, such as livestock, mining, generalized deforestation, and inadequate agriculture. In fact, deforested soils become susceptible to erosion, increasing the risk of contamination and decreasing water storage capacity in lakes and reservoirs.

\section{Collection and preparation of samples}

Sediment samples were collected using a Petersen sampler at 12 sites (S1, S2, S3, S4, S5, S6, S7, S8, S9, S10, S11, and S12) distributed over a stretch of approximately $90 \mathrm{~km}$ on the Parnaíba River (Figure 1). The selection of collection sites aimed at covering urban and agricultural areas and a high degree of preservation area, in addition to the ease of access since the collection process was carried out on a vessel. At each sampling site, five simple samples were collected, constituting a composite sample according to the standards described by ANA (2011). The collection occurred in November 2013, during the dry season. In rivers, the deposition of fine sediments occurs during the period of less precipitation and the washing of this material occurs during the season of more intense rains. In this sense, a single annual collection during the dry season can be satisfactory (ANA, 2011). After collecting, the samples were packed in 
polypropylene containers and stored in a refrigerated environment $\left(4^{\circ} \mathrm{C}\right)$. Subsequently, they were dried indoors, avoiding the sunlight, at ambient temperature $\left(20-33{ }^{\circ} \mathrm{C}\right)$.

\section{Physicochemical analyses}

The particle size analysis was performed with the combination of sedimentation and sieving tests, according to NBR 7181/1984 of ABNT (Brazilian National Standards Organization). The total organic carbon (TOC) was determined by weighing $0.5 \mathrm{~g}$ of the sediment sample in a porcelain capsule oxidized at $900{ }^{\circ} \mathrm{C}$ by means of a total organic carbon analyzer coupled to a combustion unit for solid samples. A calibration curve obtained with a standard of potassium biftalate was used for the calculations (Segnini et al., 2008).

Metal quantification was performed in the silt/clay fraction $(<63 \mu \mathrm{m})$, as recommended by the World Health Organization (WHO, 1982). For this, the sediment samples were sieved in PVC and nylon sieve with a $63-\mu \mathrm{m}$ mesh. The extraction of the metals aluminum $(\mathrm{Al})$, iron $(\mathrm{Fe})$, and manganese $(\mathrm{Mn})$ was performed by the wet method, following the method 3050B proposed by USEPA (1996). After extraction, the quantification was carried out by means of the flame atomic absorption spectrometry. The accuracy of the data was evaluated using IAEA 356 and IAEA 433 (marine sediment) certified reference materials, with a minimum confidence level of $95 \%$.

Mercury $(\mathrm{Hg})$ quantification was performed by the Zeeman atomic absorption spectrometry coupled to a pyrolysis reactor. The principle of this analysis is based on the thermal destruction of the sample, followed by the measurement of $\mathrm{Hg}$ vapor (Castilhos et al., 2006). The accuracy of the data was evaluated using a Mess 3 certified reference material (marine sediment), with a minimum confidence level of $95 \%$.

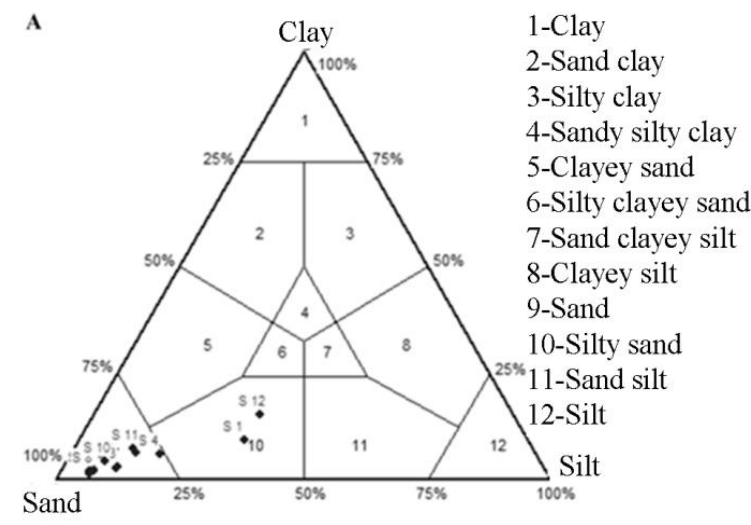

\section{Data analysis}

The data of sediment particle size were analyzed using the Shepard and Pejrup diagrams using the rysgran package (Gilbert et al., 2012) of the statistical software R. The set of physicochemical variables of sediments (sand, silt, clay, TOC, $\mathrm{Al}, \mathrm{Fe}, \mathrm{Mn}$, and $\mathrm{Hg}$ ) of the 12 sites was first submitted to the Shapiro-Wilks normality test with a $5 \%$ significance. Subsequently, all the variables were autoscaled following the guidelines described by Moita Neto \& Moita (1998). Finally, the auto-scaled dataset was simultaneously summarized in a single principal component analysis (PCA). PCA was performed on the correlation matrix (Pearson) of the variables and the criterion of PC (principal components) retention adopted was the broken-stick, i.e. with eigenvalues higher than that expected at random (Jackson, 1993). In order to interpret the meaning of the retained PCs of the original variables, only the Pearson correlation coefficients higher than $65 \%$ were considered.

\section{RESULTS AND DISCUSSION}

The results of the particle size analysis were used to classify the sediment samples regarding texture and hydrodynamics (Figure 2). The Shepard diagram (Figure 2A) showed that all sampled sites presented a sandy texture, except for S1 and S12, which presented a silty sand texture. The hydrodynamics of all sampled sites is high according to the Pejrup diagram (Figure 2B). The results of texture and hydrodynamics are coherent with each other because in environments with a high hydrodynamic energy, fine particles remain suspended and are transported to lower-energy environments, where they are sedimented (Noronha-D’Mello \& Nayak, 2015).

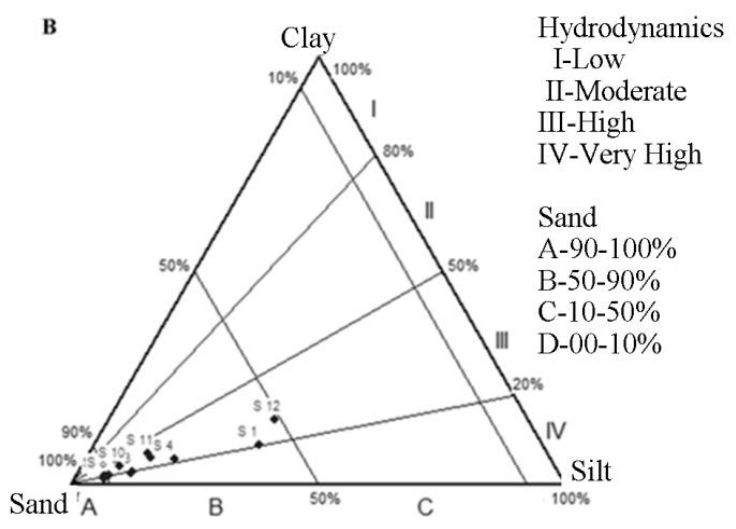

FIGURE 2. Textural composition and hydrodynamic conditions of the bottom sediment in the Parnaíba River. A: Shepard diagram; B: Pejrup diagram.

PCA is shown in Figure 3. Two PCs were considered apt to be evaluated according to the brokenstick criterion, totaling $87.24 \%$ of explanation of the data set variability (Figure 3 ). PC1 is composed of the variables silt, clay, TOC, $\mathrm{Al}$, and $\mathrm{Fe}$ in the positive quadrant and sand in the negative quadrant. PC1 separated the sampled sites into three groups: the first group was composed of S1 and S12 and presented the highest values of silt, clay, TOC, Al, and Fe; the second group was composed of S3, S5, S6, S7, S8, and S10 and presented the highest values of sand; and the third group was composed of S2, S4, S9, and S11 and presented intermediate values for the variables that compose PC1 (Figure 3). PC2 was composed of the variable $\mathrm{Hg}$ in the negative quadrant and $\mathrm{Mn}$ in the positive quadrant. PC2 separated the sampled sites into three groups: the first group was composed of S1 and S2 and presented the highest values of $\mathrm{Hg}$; the second group was composed of S10 and S12 and presented the lowest values; and the third group was composed of $\mathrm{S} 3$, S4, S5, S6, S7, S8, S9, and S11 and presented intermediate concentrations of $\mathrm{Hg}$ (Figure 3 ). 


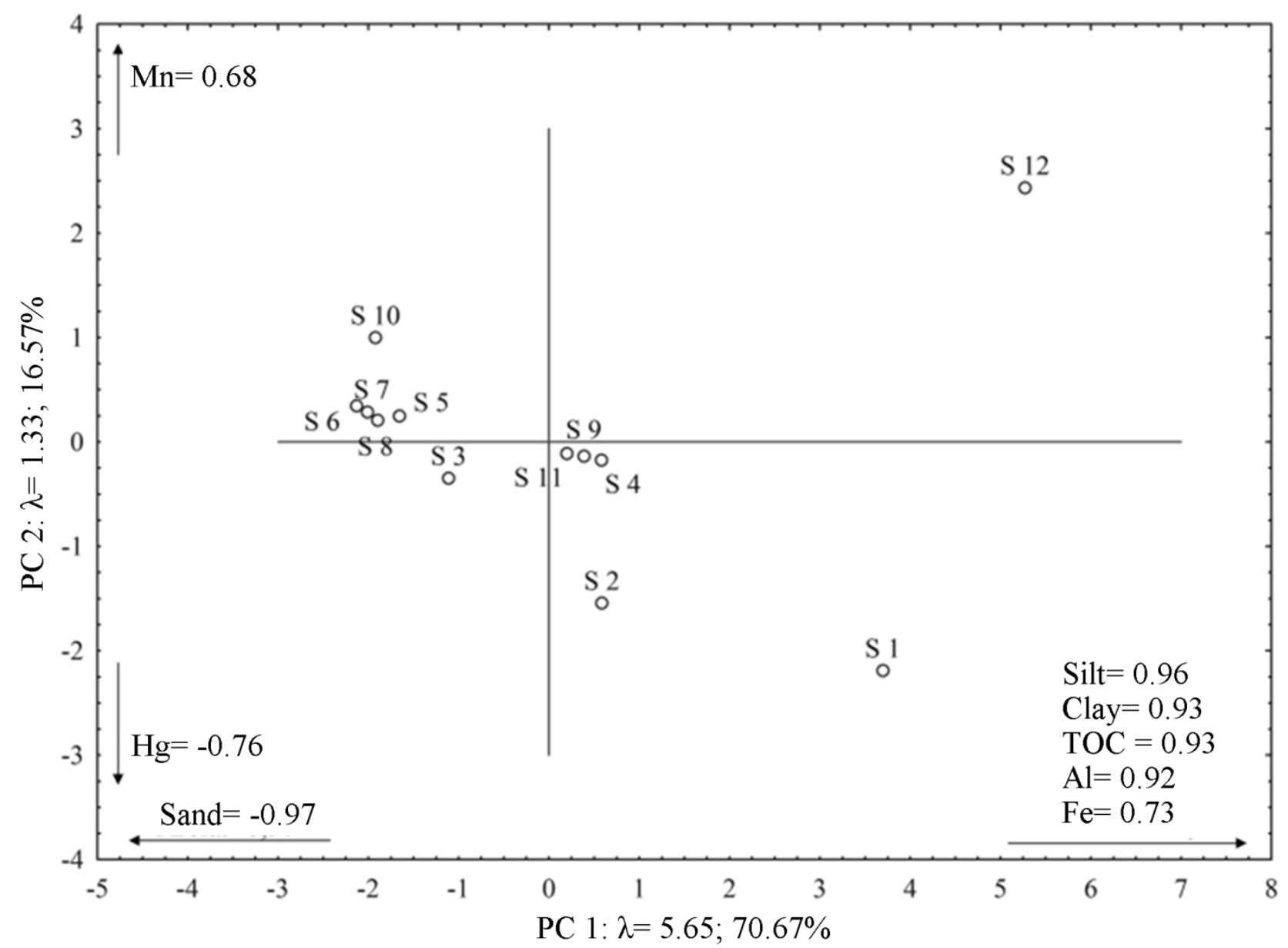

FIGURE 3. Principal component analysis of physicochemical variables of the sediment of the Parnaíba River.

According to the PCA (Figure 3), $\mathrm{Hg}$ presented a negative correlation with $\mathrm{Mn}$ and is not correlated with the natural variables clay, silt, sand, TOC, Al, and Fe. When the concentration of a metal in the sediment is positively correlated with the variables clay, silt, TOC, Al, and Fe indicates that the concentration is of geogenic origin (Davutluoglu et al., 2010; Remor et al., 2018). In this fraction, the elements are bound to silicates (Favas et al., 2015) or complexed with organic matter (Strom et al., 2011) and hence unavailable for biota. Elements of anthropogenic origin are found predominantly in the most unstable sediment fractions, which are vulnerable to small changes in environmental conditions (Bartoli et al., 2012).
Thus, it is possible that $\mathrm{Hg}$ concentrations in some collection sites are derived from anthropic activities, especially at S1, S2, and S3 (Figure 4), located near the more urbanized area of the Upper Parnaíba River basin. Other studies have reported an increase of $\mathrm{Hg}$ concentration in sediments due to urbanization (Andrade et al., 2017; Cabral et al., 2016; Cavoura et al., 2017; Hu et al., 2015). Therefore, anthropic activities have been increasing $\mathrm{Hg}$ concentration in sediments of sites near the urban areas due to the inadequate disposal of residues containing this element, such as batteries, fluorescent lamps, thermometers, electronic components, among others (Micaroni et al., 2000).

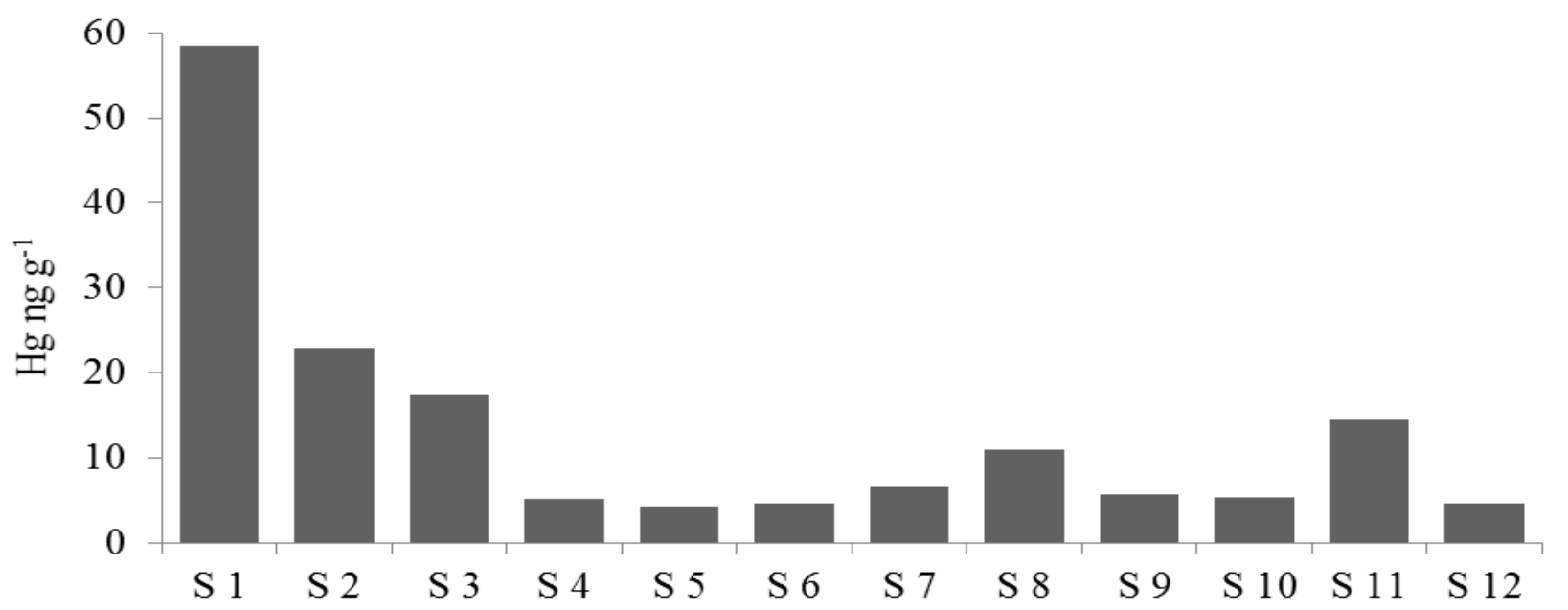

FIGURE 4. Mercury concentration in the bottom sediment of the Parnaíba River. 
The sites S4, S5, S6, S7, S8, S9, S10, S11, and S12, which are more distant from the urban area, presented lower concentrations of $\mathrm{Hg}$ in the sediment (Figure 4). In the influence area of these sites, the most relevant anthropic activities are the agriculture and livestock. Therefore, these activities are not contributing to increasing $\mathrm{Hg}$ in sediments of the Parnaíba River.

The total concentrations of $\mathrm{Hg}$ found in sediments of the Upper Parnaíba River ranged from 4.2 to $58.5 \mathrm{ng} \mathrm{g}^{-1}$ (Figure 4; Table 1). These concentrations do not present risks to biota when taking into account the limits proposed by CONAMA Resolution No. 454/2012 for sediments, in which $\mathrm{Hg}$ values below $170 \mathrm{ng} \mathrm{g}^{-1}$ present a low probability of adverse effects on biota and $\mathrm{Hg}$ concentrations above $486 \mathrm{ng} \mathrm{g}^{-1}$ would cause effects on organisms exposed to Hg. However, Castro et al. (2016) found low concentrations of $\mathrm{Hg}$ in sediments but detected higher concentrations in the muscles of carnivorous fish.
The study of Ferreira et al. (2017) in the Upper Paraguay River plateau demonstrates the bioaccumulation potential of $\mathrm{Hg}$. These researchers found $\mathrm{Hg}$ concentrations in the sediment of $100 \mathrm{ng} \mathrm{g}^{-1}$, while in the muscle of carnivorous fish of the region, it exceeded $600 \mathrm{ng} \mathrm{g}^{-1}$, evidencing their persistence and bioaccumulation. In addition, the highest concentration found in the basin (S1) is approximately 14 times higher when compared to the lowest concentration (S5) (Figure 4). In this context, detailed studies are essential in the region aiming at proving the bioaccumulative capacity and degree of $\mathrm{Hg}$ toxicity in order to quantify the risks to aquatic biota and human health (Remor et al., 2018).

The results found in our study were compared with other studies carried out in Brazilian fluvial environments, as shown in Table 1. In this sense, the values of the total $\mathrm{Hg}$ concentration found were, on average, lower when compared to those observed in other regions.

TABLE 1 . Total mercury concentration $\left(\mathrm{ng} \mathrm{g}^{-1}\right)$ in sediments of fluvial environments in Brazil.

\begin{tabular}{lllllll}
\hline Site & State & Minimum & Mean & Maximum & Impact & Reference \\
\hline Parnaíba River & PI/MA & 4.2 & 13.4 & 58.5 & M; A; U & This study \\
Lake Violão & PA & 130.0 & 240.0 & 590.0 & NR & Sahoo et al., 2015 \\
Paraíba do Sul River & RJ/MG & 22.2 & 56.1 & 158.3 & M; OF & Araujo et al., 2015 \\
Ivinhema River & MS & 25.0 & 78.0 & 125.0 & M; A & Remor et al., 2015 \\
Purus River & AC & 38.0 & 50.0 & 65.0 & NR & Castro et al., 2016 \\
Grama River & MG & 45.0 & 56.3 & 76.0 & M & Mendes et al., 2016 \\
Rico River & MG & 7.0 & 94.5 & 268.0 & M & Mendes et al., 2016 \\
Pardo River & SP & 10.0 & 20.0 & 90.0 & M; U & Machado et al., 2016 \\
Pelotas River & SC/RS & 40.5 & 48.7 & 62.0 & NR & Remor et al., 2018 \\
\hline
\end{tabular}

Impact: anthropic activities developed in the drainage basins correlated with the increase in Hg concentrations in sediments of the respective rivers cited by the authors, where: $\mathrm{M}$ - mining, $\mathrm{OF}$ - organomercurial fungicides, $\mathrm{A}$ - agriculture/livestock, $\mathrm{U}$ - urbanization, and $\mathrm{NR}$ - not reported.

Regardless of the Hg concentrations in sediments of the Upper Parnaíba River be lower than those found in other studies shown in Table 1, monitoring the sediment is essential in the region since the local population develops activities and uses this natural resource for activities of production, consumption, and recreation. In addition, the bioaccumulation characteristics, degree of toxicity, and biomagnification of $\mathrm{Hg}$ have the need to be monitored in the environment and at all trophic levels.

\section{CONCLUSIONS}

The concentrations of $\mathrm{Hg}$ found in sediments of the Upper Parnaíba River indicated a low probability of adverse effects on biota. However, $\mathrm{Hg}$ concentration at sites near the urban area is higher than in other sampled sites. In this sense, it is necessary to monitor a possible increase in the $\mathrm{Hg}$ concentration in the sediment caused by urbanization and verify whether the current levels can cause damage to biota and human health due to its high toxicity, persistence, and bioaccumulation in the environment.

\section{ACKNOWLEDGEMENTS}

The authors gratefully acknowledge the financial support of the National Council for Scientific and Technological Development (Conselho Nacional de Desenvolvimento Científico e Tecnológico - CNPq), Coordination for the Improvement of Higher Education Personnel (Coordenação de Aperfeiçoamento de Pessoal de Nível Superior - CAPES),State University of Western Paraná (Universidade Estadual do Oeste do Paraná UNIOESTE), and the Pos Graduate Programin Agricultural Engineering (Programa de Pós-graduação em Engenharia Agrícola - PGEAGRI).

\section{REFERENCES}

ANA - Agência Nacional de Águas. Guia nacional de coleta e preservação de amostras: água, sedimento, comunidades aquáticas e efluentes líquidos / Companhia Ambiental do Estado de São Paulo. CETESB, ANA. 326p.

Andrade RLB, Hatje V, Masqué P, Zurbrick CM, Boyle EA, Santos WPC (2017) Chronology of anthropogenic impacts reconstructed from sediment records of trace metals and $\mathrm{Pb}$ isotopes in Todos os Santos Bay (NE Brazil). Marine Pollution Bulletin 125(1-2):459-471. DOI: http://dx.doi.org/10.1016/j.marpolbul.2017.07.053. 
Araujo BF, Almeida MG, Rangel TP, Rezende CE (2015) Distribuição e fracionamento do $\mathrm{Hg}$ em sedimentos do rio Paraíba do Sul - RJ Brasil. Química Nova 38:30-36. DOI: http://dx.doi.org/10.5935/0100-4042.20140268.

Bai J, Jia J, Zhang G, Zhao Q, Lu Q, Cui B, Liu X (2016) Spatial and temporal dynamics of heavy metal pollution and source identification in sediment cores from the shortterm flooding riparian wetlands in a Chinese delta. Environmental Pollution 219:379-388. DOI: http://dx.doi.org/10.1016/j.envpol.2016.05.016.

Bartoli G, Papa S, Sagnella E, Fioretto A (2012) Heavy metal content in sediments along the Calore river: relationships with physical-chemical characteristics. Journal of Environmental Management 95:S9-S14. DOI: http://dx.doi.org/10.1016/j.jenvman.2011.02.013

Begy RC, Preoteasa L, Timar-Gabor AT, Mihăiescu R, Tănăselia C, Kelemena, Simon H (2016) Sediment dynamics and heavy metal pollution history of the Cruhlig Lake (Danube Delta, Romania). Journal of Environmental Radioactivity 153:167-175. DOI:

http://dx.doi.org/10.1016/j.jenvrad.2015.12.020.

Cabral L, Lacerda Júnior GV, Sousa STP, Dias ACF, Cadete LL, Andreote FD, Hess M, Oliveira VM (2016) Anthropogenic impact on mangrove sediments triggers differential responses in the heavy metals and antibiotic resistomes of microbial communities. Environmental Pollution 216:460-469. DOI: http://dx.doi.org/10.1016/j.envpol.2016.05.078

Castilhos ZC, Rodrigues S, Rodrigues APC, Villas-Boas RC, Siegel S, Veiga M, Beinhoff C (2006) Mercury Contamination in Fish from Gold Mining Areas in Indonesia and Human Health Risk Assessment. Science of the Total Enviromental 368:320-325. DOI: http://dx.doi.org/10.1016/j.scitotenv.2006.01.039

Castillo MA, Trujillo IS, Alonso EV, Torres AG, Pavón JC (2013) Bioavailability of heavy metals in water and sediments from a typical Mediterranean Bay (Málaga Bay, Region of Andalucía, Southern Spain). Marine Pollution Bulletin 76:427-434. DOI:

http://dx.doi.org/10.1016/j.marpolbul.2013.08.031

Castro NSS, Braga CM, Trindade PAA, Lima MO (2016) Mercury in fish and sediment of Purus River, Acre State, Amazon. Cadernos Saúde Coletiva 24:294-300. DOI: http://dx.doi.org/10.1590/1414-462x201600030142

Cavoura O, Brombach CC, Cortis R Davidson CM, Gajdosechova Z, Keenan HE, Krupp EM (2017) Mercury alkylation in freshwater sediments from Scottish canals. Chemosphere 183:27-35. DOI:

http://dx.doi.org/10.1016/j.chemosphere.2017.05.077

Davutluoglu IO, Seckin G, Kalat DG, Yilmaz T, Ersu CB (2010) Speciation and implications of heavy metal content in surface sediments of Akyatan Lagoon - Turkey. Desalination 260:199-210. DOI: http://dx.doi.org/10.1016/j.desal.2010.04.031

Favas PJC, Sarkar SK, Rakshit D (2015) Geochemical fractionation of trace elements in stream sediments contaminated by mining activity. Clean Soil Air Water 43:446-455. DOI:

http://dx.doi.org/10.1002/clen.201200718
Ferreira CMA, Egler SGE, Yallouz AV, Ignácio ÁRA

(2017) Semiquantitative determination of total mercury in Pygocentrus nattereri Kner, 1858 and sediment at the plateau of Upper Paraguai River, Brazil. Chemosphere 174:604-612. DOI:

http://dx.doi.org/10.1016/j.chemosphere.2017.01.059

Franklin RL, Bevilacqua JE, Favaro DIT (2012) Organic and total mercury determination in sediments by cold vapor atomic absorption spectrometry: methodology validation and uncertainty measurements. Química Nova 35:45-50. DOI: http://dx.doi.org/10.1590/S010040422012000100009

Franz C, Makeschin F, Weiß H, Lorz C (2013) Geochemical signature and properties of sediment sources and alluvial sediments within the Lago Paranoá catchment, Brasilia DF: A study on anthropogenic introduced chemical elements in an urban river basin. Science of The Total Environment (452-453):411-420. DOI: http://dx.doi.org/10.1016/j.scitotenv.2013.02.077

Franz C, Makeschin F, Weiß H, Lorz C (2014) Sediments in urban river basins: Identification of sediment sources within the Lago Paranoá catchment, Brasilia DF, Brazil using the fingerprint approach. Science of The Total Environment (466-467):513-523. DOI: http://dx.doi.org/10.1016/j.scitotenv.2013.07.056

Freitas RE, Mendonça MAA (2016) Expansão Agrícola no Brasil e a Participação da Soja: 20 anos. Revista de Economia e Sociologia Rural 54:497-516. DOI: http://dx.doi.org/10.1590/1234-56781806-94790540306

Garcia JR, Buainain AM (2016) Dinâmica de Ocupação do Cerrado Nordestino pela Agricultura: 1990 e 2012. Revista de Economia e Sociologia Rural 54:319-338. DOI: http://dx.doi.org/10.1590/1234.56781806-947900540207

Gibb H, O'leary KG (2014) Mercury exposure and health impacts among individuals in the artisanal and small-scale gold mining community: A comprehensive review. Environmental Health Perspectives 122:667-672. DOI: http://dx.doi.org/10.1289/ehp.1307864.

Gilbert ER, Camargo MG, Sandrini-Neto L (2012) Rysgran: Grain size analysis, textural classifications and distribution of unconsolidated sediments. R package version 2.0 .

Hu G, Bi S, Xu G, Zhang Y, Mei X, Li A (2015) Distribution and assessment of heavy metals off the Changjiang River mouth and adjacent area during the past century and the relationship of the heavy metals with anthropogenic activity. Marine Pollution Bulletin 96 (1-2):434-440. DOI: http://dx.doi.org/10.1016/j.marpolbul.2015.05.009.

Jackson DA (1993) Stopping Rules in Principal Components Analysis: A comparison of heuristical and statistical approaches. Ecology 74:2204-2214. 
Kim K, Kabir E, Jahan SA (2016) A review on the distribution of $\mathrm{Hg}$ in the environment and its human health impacts. Journal of Hazardous Materials 306:376-385. DOI: http://dx.doi.org/10.1016/j.jhazmat.2015.11.031

Machado CS, Alves RIS, Fregonesi BM, Tonani KAA, Martinis BS, Sierra J, Nadal M, Domingo JL, SeguraMuñoz S (2016) Chemical Contamination of Water and Sediments in the Pardo River, São Paulo, Brazil. Procedia Engineering 162:230-237. DOI:

http://dx.doi.org/10.1016/j.proeng.2016.11.046

Mendes LA, Lena C, Valle CM, Fleming PM, Windmöller CC (2016) Quantification of methylmercury and geochemistry of mercury in sediments from a contaminated area of Descoberto (MG), Brazil. Applied Geochemistry 75:32-43. DOI:

http://dx.doi.org/10.1016/j.apgeochem.2016.10.011

Micaroni RCCM, Bueno MIMS, Jardim WF (2000) Compostos de mercúrio. Revisão de métodos de determinação, tratamento e descarte. Química Nova 23(4):487-495. DOI: http://dx.doi.org/10.1590/S010040422000000400011

Moita Neto JM, Moita GC (1998) Uma introdução à análise exploratória de dados multivariados. Química Nova 21(4):467-469. DOI:

http://dx.doi.org/10.1590/S0100-40421998000400016

Molamohyeddin N, Ghafourian H, Sadatipour SM (2017)

Contamination assessment of mercury, lead, cadmium and arsenic in surface sediments of Chabahar Bay. Marine Pollution Bulletin 124(1):521-525. DOI: http://dx.doi.org/10.1016/j.marpolbul.2017.07.035

Motta EJO, Gonçalves NEW (2016) Plano nascente Parnaíba: Plano de preservação e recuperação de nascentes da bacia do rio Parnaíba. Brasília, Companhia de Desenvolvimento dos Vales do São Francisco e do Parnaíba, Editora IABS. p45-46.

Noronha-D'Mello CA, Nayak GN (2015) Geochemical characterization of mangrove sediments of the Zuari estuarine system, West coast of India. Estuarine, Coastal and Shelf Science 167:313-325. DOI:

http://dx.doi.org/10.1016/j.ecss.2015.09.011.

Oliveira GA, Rocha GC, Macedo JAB, Britto MC (2013) Percepção de risco à contaminação por mercúrio em uma antiga área de garimpo de ouro em descoberto/MG. Revista de geografia 2(2):1-6.

Poitrasson F, Vieira C, Seyler P, Pinheiro GMS, Mulholland DS, Bonnet MP, Martinez JM, Lima BA, Boaventura GR, Chmeleff J, Dantas EL, Guyot JL, Mancini L, Pimentel MM, Santos RV, Sondag F, Vauchel P (2014) Iron isotope composition of the bulk waters and sediments from the Amazon River Basin. Chemical Geology 377(4):1-11. DOI: http://dx.doi.org/10.1016/j.chemgeo.2014.03.019

Remor MB, Sampaio SC, Damatto SR, Castilhos ZC, Stevaux JC, Vilas Boas MA, dos Reis RR (2015) Geochemistry of the Upper Paraná River floodplain: study of the Garças Pond and Patos Pond. Journal of Radioanalytical and Nuclear Chemistry 305:409-418. DOI: http://dx.doi.org/10.1007/s10967-015-4021-9
Remor MB, Sampaio SC, Model KJ, Falco D, Prudente VHR (2018) Mercury in the sediment of Pelotas river basin, Brazil. Engenharia Agrícola 38(1):117-123. DOI: http://dx.doi.org/10.1590/1809-4430-eng.agric.v38n1p117$123 / 2018$

Resongles E, Casiot C, Freydierr, Dezileau L, Viers J, Elbaz-Poulichet F (2014) Persisting impact of historical mining activity to metal $(\mathrm{Pb}, \mathrm{Zn}, \mathrm{Cd}, \mathrm{Tl}, \mathrm{Hg})$ and metalloid (As, $\mathrm{Sb}$ ) enrichment in sediments of the Gardon River, Southern France. Science of The Total Environment 481:509-521. DOI:

http://dx.doi.org/10.1016/j.scitotenv.2014.02.078.

Sahoo PK, Souza-Filho PWM, Guimarães JTF, Silva MS, Costa FR, Manes CLO, Oti D, Silva Júnior RO, Dall'agnol $\mathrm{R}$ (2015) Use of multi-proxy approaches to determine the origin and depositional processes in modern lacustrine sediments: Carajás Plateau, theastern Amazon, Brazil. Applied Geochemistry 52:130-146. DOI: http://dx.doi.org/10.1016/j.apgeochem.2014.11.010

Santos CO (2015) Espírito do capitalismo na ocupação dos cerrados brasileiros nos estados da Bahia e do Piauí. Revista de Geografia e Ordenamento do Território 8:229253. DOI: http://dx.doi.org/10.17127/got/2015.8.012

Segnini A, dos Santos LM, da Silva WTL, Martin-Neto L, Borato CE, de Melo WJ, Bolonhezi D (2008) Estudo comparativo de métodos para a determinação da concentração de carbono em solos com altos teores de $\mathrm{Fe}$ (Latossolos). Química Nova 31:94-97. DOI: http://dx.doi.org/10.1590/S0100-40422008000100020

Selin NE (2014) Global change and mercury cycling: Challenges for implementing a global mercury treaty. Environmental Toxicology and Chemistry 33(6):12021210. DOI: http://dx.doi.org/10.1002/etc.2374

Silva LFO, Vallejuelo SFO, Martinez-Arkarazo I, Castro K, Oliveira MLS, Sampaio CH, Brum IAS, Leão FB, Taffarel SR, Madariaga JM (2013) Study of environmental pollution and mineralogical characterization of sediment rivers from Brazilian coal mining acid drainage. Science of The Total Environment 447(1):169-178. DOI: http://dx.doi.org/10.1016/j.scitotenv.2012.12.013

Strom D, Simpson SL, Batley GE, Jolley DF (2011) The influence of sediment particle size andorganic carbon on toxicity of copper to benthic invertebrates in oxic/suboxic surface sediments. Environmental Toxicology. Chemistry 30:1599-610. DOI: http://dx.doi.org/10.1002/etc.531

Syversen T, Kaur P (2012) The toxicology of mercury and its compounds. Journal of Trace Elements in Medicine and Biology 26:215-226. DOI: http://dx.doi.org/10.1016/j.jtemb.2012.02.004 
Ullrich SM, Tanton TW, Abdrashitova SA (2001) Mercury in the aquatic environment: a review of factors affecting methylation. Critical Reviews in Environmental Science and Technology 31:241-293. DOI:

http://dx.doi.org/10.1080/20016491089226

UNEP - United Nations Enviromental Programs (2017) Minamata convention on mercury. UNEP. Available in: http://www.mercuryconvention.org/Convention/tabid/3426 /language/en-US/Default.aspx. Accessed: Jul 26, 2018.

USEPA - United States Environmental Protection Agency (1996) Method 3050B. Acid digestion of sediments sludges and soils. Available in:

http://www.epa.gov/homeland-security-research/epamethod-3050b-acid-digestion-sediments-sludges-and-soils. Accessed: Nov 21, 2017.
Voigt CL, Silva CP, Campos SX (2016) Assessment of bioaccumulation of metals in cyprinus carpio by interaction with sediment and water in a reservoir. Química Nova 39:180-188. DOI:

http://dx.doi.org/10.5935/0100-4042.20160014

WHO - World Health Organization (1982)

Micropollutants in river sediments. Copenhage, World Health Organization, p85.

Zhang C, Yu Z, Zeng G, Jiang M, Yang Z, Cui F, Zhu M, Shen L, Hu L (2014) Effects of sediment geochemical properties on heavy metal bioavailability. Environment International 73:270-281. DOI:

http://dx.doi.org/10.1016/j.envint.2014.08.010 